\title{
Teaching Social Sciences through Ethnophotography
}

\author{
Titik Haryati $^{1}$ and Oktaviani Adhi Suciptaningsih ${ }^{2}$ \\ ${ }^{1}$ FPIPSKR, University of PGRI Semarang \\ ${ }^{2}$ FIP, University of PGRI Semarang \\ Permalink/DOI: http://dx.doi.org/10.15294/komunitas.v7i2.4841 \\ Received : August 2015; Accepted: September 2015; Published: September 2015
}

\begin{abstract}
Curriculum 2013 requires teachers to be more creative in compiling teaching materials which are innovative, varied, exciting, contextual, and in accordance with learners' needs to achieve learning objectives. This research aims at developing IPS materials for VII graders of Junior High School (SMP) based on ethnophotography. This study used Research and Development design $(R \& D)$. The results were analyzed by qualitative analysis technique. The results show that most social studies (IPS) teachers have not yet developed the IPS materials for VII graders of SMP which is relevant to the environmental conditions. The ethnophotography was used to determine the development of IPS materials by photographing/taking pictures of each regional potential to be used as supporting material in IPS materials. Through ethnophotography, the students would be more interested and easier to learn the material, and at the same time, they learn a variety of region's potential. In conclusion, the IPS material based on ethnophotography can be used as one of the ways to develop teaching materials to get more effective and efficient learning because students can easily understand the material through the photographs displayed in the teaching materials because the photographs show a variety of things around it.
\end{abstract}

Keywords: teaching materials development; IPS; VII graders of SMP; ethnophotography

\section{INTRODUCTION}

In accordance with the Article 2 of Act No. 20 of 2003 on National Education System, our national education is based on Pancasila and the Constitution of the Republic of Indonesia 1945. Article 3 confirms that national education serves to develop the ability and character development as well as dignified civilization in framework of educating the nation. It aims to develop students' potentials to become a man of faith and fear of God Almighty, noble, healthy, knowledgeable, capable, creative, independent, and become responsible citizens of a democratic country.

To realize the goal of national education, it requires qualifications of graduates, including the ability, attitudes, knowledge, and skills of learners which they must achieve from educational unit on elementary and secondary education.

\footnotetext{
Corresponding author:

Address: Perum Ayodya Klaster Bambu No. 17 Banaran Gunungpati Semarang, Central Java, Indonesia

Email : titikh30@gmail.com

Telp : 085640631010
}

The graduates of SMP/MTs/SMPLB/ Paket $\mathrm{B}$ have the attitude (behavior that reflects the attitude of the faithfulness, noble, knowledgeable, confident, and responsible to interact effectively with the social and natural environment within reach of the association and its existence), knowledge (having factual knowledge, conceptual and procedural in science, technology, arts, and culture with insight into humanity, nationality, state, and civilization-related phenomena and events that looked the eye), and skills (the ability of thinking and followeffective and creative in the realm abstract and concrete in accordance with the learned in school and other similar sources).

In 2013 curriculum of standard competencies are described in textbooks, in which the textbook has been provided by the government. The teachers and students are expected to use the book as a learning

(C) 2015 Semarang State University. All rights reserved p-ISSN 2086 - 5465 | e-ISSN 2460-7320

UNNDS JOURNALS 
guide for both of them. Student books have explained the minimal effort for learners to achieve the expected competencies. In the process of learning, learners are encouraged to seek from other learning resources available and sprawling surroundings (Johnson and Johnson 2009). Therefore, the teacher's role is very important in improving and adjusting the absorption of learners with the available activities stated in the book. Teachers are expected to enrich it with the creation of other forms and activities that are relevant for social and natural environment of each region (Kemdikbud 2013). This means that every teacher is expected to develop and adjust instructional materials according to their potentials (Ferguson and Sharples 2014; Dede 2009; Moran and Tegano 2005; Latham and Mccormack 2007; Davis and Krajcik 2005; Meo 2008).

The teacher as the main controller in the learning process of classroom needs to look first to the student books and teacher manuals that have been provided by the government. It is necessary to be thorough on the book provided by the government aimed for the purposes of a national scale. Therefore, local-based learning resource is important to be considered.

Former studies suggest that in a time of increasing plurality in today's world, it is essential that students become critically competent citizens. This can be achieved for example by providing creative learning and teaching of social sciences (Johnson and Johnson 2009; Ferguson and Sharples 2014; Moran Tegano 2005; Meo 2008; Davis and Krajcik 2005). This article attempts to explore such efforts by discussing creative teaching through ethnophotography. Etnophotography is a method for deeply exploring the potential of society and culture in a certain place (Green and Bloome 2004; Atkinson and Pugsley 2005; Ferguson and Sharples 2014). Through Etnophotography, teachers can develop teaching materials within students' and teachers' books from social and natural environment of each region so that it can be relevant to the situation and will help students understanding the material better. It is necessary for further development in order to produce teaching materials of social sciences (IPS) for VII graders of junior high school (SMP) based on appropriate Etnophotography.

\section{RESEARCH METHODS}

This study employed a research and development. According to Sukmadinata (2007, p.164), research and development is a powerful strategy or method on research to improve practice. According to Borg and Gall (1983), research and development activities include a series of stages of product development (year 1), testing of products (year 2), and product revision (year 2). The subjects of the study were IPS teachers and VII graders in SMP 2 Semarang, IPS teacher and VII graders in SMP 5 Semarang, and IPS teacher and VII graders in SMP Is. Roudlotus Saidiyah Gunung Pati. The data was collected through interviews, observation, and documentation. Technique validity of the data used triangulation, while the phase analysis techniques used data analysis, data reduction, data compilation to unit, categorization, data validity checking. The data analysis and interpretation was based the theory and concepts used.

\section{RESULTS AND DISCUSSIONS}

In accordance with the concept of Curriculum 2013, IPS subject for VII graders in SMP is compiled based on integrated social sciences learning. Learning for each subject should be continued to make students skilled in presenting knowledge both for concrete and abstract aspects. Learning is aimed at providing a complete insight for junior high school students about the concepts of space and time connectivity along with social activities.

Here is the identity of IPS Textbooks for SMP / MTs VII grade Revised Edition 2014:

Book Name: Ilmu Pengetahuan Sosial Kuri-
kuum 2013 Edisi Revisi 2014 SMP/
MTs Kelas VII
Contributors: Ahmad Mushlih, Iwan Se-
tiawan, Suciati, and Dedi
Reviewers: Mukminan, Slamet Achmad, Siti 
Irene Astuti, and Tri Wahyuning

Publishing supervisor: Curriculum Center and of Books, Research, Kemdikbud

ISBN: 978-602-282-325-4

Number of Pages: 281 Pages

The Front cover of IPS Textbooks for SMP / MTs Class VII Revised Edition 2014 is as follows:

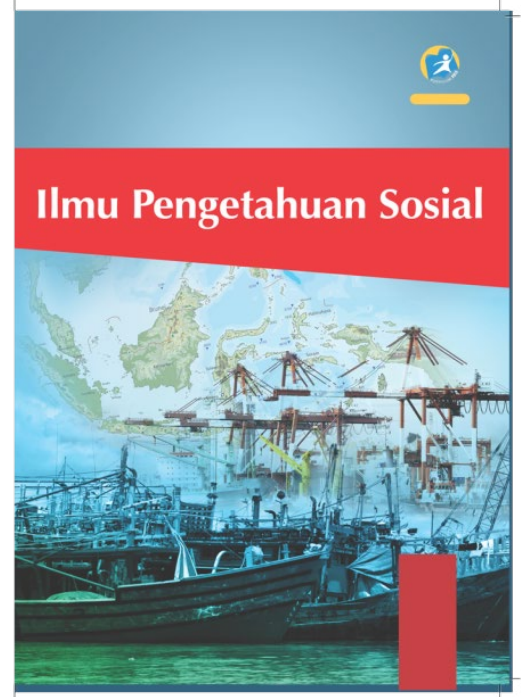

Picture 1. Front Cover Book

Inside the book, Geography is used as the basis (platform) of discussion of other disciplines. Through a general idea of the Republic of Indonesia (NKRI), the students are introduced to the diversity of the potential of each region. The potential diversity creates supply-demand dynamics dimensions of space and time which triggers the importance of multi-dimensional connectivity bond formation, so it will generate solid unity in existing diversity.

The discussion is divided based on diverse development capitals owned by the state and nation, namely human capital, location capital, natural resources capital, and cultural resources capital (including indigenous people). Understanding of the capitals of this development will strengthen confidence, love and pride of the students for the excellence of their Homeland, thus growing awareness to manage, utilize and conserve the capitals that are responsible for the prosperity and progress (Book IPS Class
VII SMP).

In order to achieve learning objectives, an IPS teacher is required to be able to develop teaching materials in accordance with the social and natural environment of each region so that it can be relevant to the situation. Therefore, textbooks provided by the government are made on a national scale; a wide variety of material presented is national-based. Therefore, teachers should develop teaching materials IPS in accordance with the local environmental conditions around the students.

Development of teaching materials becomes one of the things that are important in the achievement of learning objectives. Teaching materials is a set of knowledge, attitudes, and skills that must be learned by the students in order to achieve standard competence which have been determined. In detail, the types of learning materials consist of knowledge (including facts, concepts, principles, and procedures), skills, and attitudes or values (Djelita 2013; Haji 2011; Mulyana Elih, et al. 2013; Harijanto 2007).

The forms of teaching material are divided into three forms, namely: first, teaching materials according to their form: printed teaching materials, for example handouts, books, modules, worksheets, brochures, leaflets, wall chart, photos/ images, and models/mockups, teaching materials for listening/audio programs, for example, cassette, radio, LPs and audio CDs, instructional materials for audiovisual, for example, VCD and films and interactive teaching materials, for example, audio, text, graphics, images, animation, and video). Second, teaching materials according to how it works: teaching materials that are not projected, for example, photographs, charts display, teaching materials that are projected, for example, slides, filmstrips, overhead transparencies, projection computer, Audio teaching materials, for example Compo tape, CD player, multimedia player, flash disk, Video teaching materials video, for example, VCD player, DVD player, Computer teaching materials, for example, computer assisted instruction and computer- 
based multimedia/hypermedia. And third, teaching materials according to its nature, print-based teaching materials, for example books, tutorial materials, technology-based materials, such as radio broadcasts, and films, practice-based materials, for example, science kits, observation sheets, teaching materials required for the purposes of human interaction, especially for distance education purposes such as telephone, mobile phone.

Instructional materials have the following benefits (Putrayasa 2011):

1. The use for teachers: teachers will have teaching materials that can assist in the implementation of learning activities. Teaching material can be submitted as a work to increase the number of educators' credit for the purpose of promotion and increase revenue for educators if their works are published.

2. The use for students: learning activities becomes more attractive, more students will have the opportunity to learn independently with the guidance of educators, and students find it easy to learn each competency that should be mastered.

In the implementation, the majority of IPS teachers for VII graders of SMP have not yet developed teaching materials in accordance with the potential of each area. IPS teachers still use textbooks from the government as the main textbook in IPS class, including in SMP 2 Semarang, SMP 5 Semarang, and SMP Is. Roudlotus Saidiyyah Gunungpati, Semarang. Three IPS teachers in those schools have not yet developed teaching materials based on local potentials; they tend to develop materials orally using a variety of learning approaches that are contextual.

The condition is in accordance with the statement of some IPS teachers in those schools, "....... in teaching social studies, we use a book that has been provided by the government, with contextual learning model, namely the attempt to relate the material to the issues raised in the community, ....... because the curriculum in 2013 are new so we have not had time to develop teaching materials “.

This is also expressed by students, that IPS is a difficult subject because there are many things to be learned, ranging from Sociology, Anthropology, Geography, so it tends to require memorization, as expressed by some students, "......... social studies is difficult, a lot of memorization, a lot to learn, because 3 materials are combined into one ......" ".

Therefore, teacher's role is very important in making learning social studies in order to be more fun so that students are interested and able to understand the material easily. Junior high school students in psychology enter the domain of early adolescence, in which one of the characteristics of its development is to like things that are visual, such as drawings, comics, photographs, and so forth. This is consistent with the statement of Astuti, et al. (2014) which states that students are more interested in exciting and familiar image visualization.

Development of IPS teaching materials for VII graders which is in accordance with the potential of each region can be done with etnophotography. Etnophotography is a study in anthropology and photography that emphasizes on the incredibility of the things that are conventional. Etnophotography, is a blend of ethnography and photography. As a method, etnophotography uses the work of ethnography by the medium of photography to support the good work in data collection, analysis, and results. Hence, the use of visual materials (photographic) becomes the main material for doing the ethnography (Collier, John, and Collier, Malcolm 1986; Rikhmawan 2012).

Development of IPS teaching materials for VII graders of SMP based on etnophotography has the following objectives:

1. Meeting the demands of curriculum in 2013 about the necessity of teachers to develop teaching materials in accordance with the potential of each region.

2. Introducing the students about the different kinds of potential in the region. 
Table 1. Photos of Central Java's potentials that are used in the IPS book for VII graders

\begin{tabular}{|c|c|c|}
\hline No. & IPS Materials & Photos of Central java Potentials \\
\hline 1 & Nature (Beach) & Bandengan Beach, Jepara \\
\hline 2 & $\begin{array}{l}\text { Agricultural land ter- } \\
\text { racing }\end{array}$ & $\begin{array}{l}\text { Faring in Dieng Plateau, Area in Umbul Sidomukti Hill, } \\
\text { Bandungan }\end{array}$ \\
\hline 3 & Plateau & Dieng Wonosobo \\
\hline 4 & Tea Plantation & $\begin{array}{l}\text { Tea plantation of Tawang Mangu Solo, Tea Plantation Me- } \\
\text { dini }\end{array}$ \\
\hline 5 & Temple & $\begin{array}{l}\text { Borobudur Temple, Gedong Songo Temple Ungaran, Su- } \\
\text { kuh Temple }\end{array}$ \\
\hline 6 & $\begin{array}{l}\text { Places of Worship for } \\
\text { several religions }\end{array}$ & $\begin{array}{l}\text { Menara Kudus Mosque, Blendug Kota Church Semarang, } \\
\text { Sedaleman Pura Karanganyar, Avalokitesvara Pagoda in } \\
\text { Buddhagaya Vihara Watugong Semarang }\end{array}$ \\
\hline 7 & Slum Area & Jebres Solo \\
\hline 8 & $\begin{array}{l}\text { Natural Resources (Ma- } \\
\text { rine) }\end{array}$ & Karimunjawa Beach \\
\hline 9 & Reservoir & Gajah Mungkur Reservoir Wonogiri \\
\hline 10 & Tropical Rain Forest & Boja Kendal Tropical Rain Forest \\
\hline 11 & Mangrove Forest & Mangrove Forest Karimunjawa \\
\hline 12 & Coral Reef & Karimunjawa Sea \\
\hline 13 & Wet Land Agriculture & Agricultural Area in Demak, Kendal, Wonosobo \\
\hline 14 & Cattle Farm & Boyolali \\
\hline 15 & Wooden Furniture & Mebeler Jepara \\
\hline 16 & Tourism Sites & Kartini Jepara Beach, White Sand Beach Karimunjawa \\
\hline 17 & Endemic Species & Kantil Flower, Golden Kepodang Bird \\
\hline 18 & Pre-historical life & Sangiran Museum \\
\hline 19 & Beach Abrasion & Marina Beach Semarang \\
\hline 20 & Trade Center & $\begin{array}{l}\text { Klewer Market Solo, Johar Market, and Bulu Market } \\
\text { Semarang }\end{array}$ \\
\hline
\end{tabular}

3. Facilitating the students in learning the material.

4. Making it easier for teachers to provide materials that are relevant to the potential of the surrounding area.

5. Enriching IPS teaching materials for VII graders.

The most important thing to do in developing teaching materials based on etnophotography is selecting and sorting the photos of Central Java's potential in accordance with the material. This is done by photographing/taking pictures in thirteen (13) cities / regencies in Central Java, Semarang City, Semarang regency, Kendal re- gency, Demak regency, Kudus regency, Pati regency, Jepara regency, Wonosobo regency, Magelang regency, Banjarnegara regency, Wonogiri regency, Surakarta City, Cilacap regency. After taking some photos that are tailored to the material, then we must select photos that depict the most appropriate potentials in terms of material representation, the sharpness of the colors in an image, the proportion of photos, and so forth.

Based on the above development of IPS teaching materials for VII graders of SMP, the supporting IPS book based on local potential is created: IPS Textbook for VII graders SMP based on Etnophotography 
Table 2. Development of IPS textbooks for VII graders based on etnophotography by using the steps in the development of teaching materials presented by Prastowo

\begin{tabular}{|c|c|c|c|}
\hline No. & Stages & Steps & Aspects \\
\hline \multirow[t]{3}{*}{1.} & $\begin{array}{l}\text { The analysis of IPS } \\
\text { teaching materials } \\
\text { needs for VII grad- } \\
\text { ers SMP }\end{array}$ & ranalyzing curriculum & $\begin{array}{l}\text { standard competence }(\mathrm{SK}) \\
\text { Basic competence }(\mathrm{KD}) \\
\text { Learning achievement indicators } \\
\text { Main Materials } \\
\text { Learning Experience }\end{array}$ \\
\hline & & $\begin{array}{l}\text { Analyzing } \\
\text { sources }\end{array}$ & $\begin{array}{l}\text { availability of learning sources } \\
\text { suitability of learning sources } \\
\text { with learning objectives } \\
\text { ease and use of learning sources }\end{array}$ \\
\hline & & $\begin{array}{l}\text { choosing and selecting } \\
\text { learning sources }\end{array}$ & $\begin{array}{l}\text { paying attention to three prin- } \\
\text { ciples of relevance of SKKD, con- } \\
\text { sistency with KD, and material } \\
\text { coverage for mastering KD } \\
\text { SKKD identifying aspects within } \\
\text { SKKD } \\
\text { identifying the types of learning } \\
\text { materials }\end{array}$ \\
\hline 2. & $\begin{array}{l}\text { understanding the } \\
\text { criteria for selec- } \\
\text { tion of learning } \\
\text { resources }\end{array}$ & $\begin{array}{ll}\text { understanding } & \text { general } \\
\text { criteria } & \\
\text { understanding } & \text { specific } \\
\text { criteria } & \end{array}$ & $\begin{array}{l}\text { Economical, practical, simple, } \\
\text { easy to find, and flexible. } \\
\text { Learning resources can motivate } \\
\text { learners in learning, learning } \\
\text { resources for teaching, learning } \\
\text { resources for research, learning } \\
\text { resources for problem solving, } \\
\text { and learning resources for pre- } \\
\text { sentation. }\end{array}$ \\
\hline 3. & $\begin{array}{l}\text { mapping out the } \\
\text { IPS teaching ma- } \\
\text { terials for VII } \\
\text { Graders SMP }\end{array}$ & $\begin{array}{l}\text { knowing the amount of } \\
\text { teaching materials to be } \\
\text { written down } \\
\text { knowing the sequence of } \\
\text { teaching materials } \\
\text { deciding the nature of } \\
\text { teaching materials }\end{array}$ & $\begin{array}{l}\text { material needs } \\
\text { determining the priority of writ- } \\
\text { ing } \\
\text { understanding the nature of } \\
\text { teaching material which is "de- } \\
\text { pendent" }\end{array}$ \\
\hline 4. & $\begin{array}{l}\text { creating IPS } \\
\text { teaching materi- } \\
\text { als for VII graders } \\
\text { SMP based on the } \\
\text { forms/structures } \\
\text { of materials }\end{array}$ & $\begin{array}{l}\text { printed materials struc- } \\
\text { ture }\end{array}$ & $\begin{array}{l}\text { books (consists of title, KD, ma- } \\
\text { terials, exercise, and evaluation) } \\
\text { Images/Photos (KD/materials, } \\
\text { supporting information, assign- } \\
\text { ments/step, evaluation) }\end{array}$ \\
\hline
\end{tabular}


of Central Java. The book contains photographs of the potential of Central Java (both natural resources (biotic, abiotic) and $\mathrm{Hu}^{-}$ man Resources) which is adapted to the material. The following are examples of area potential photos in the book:
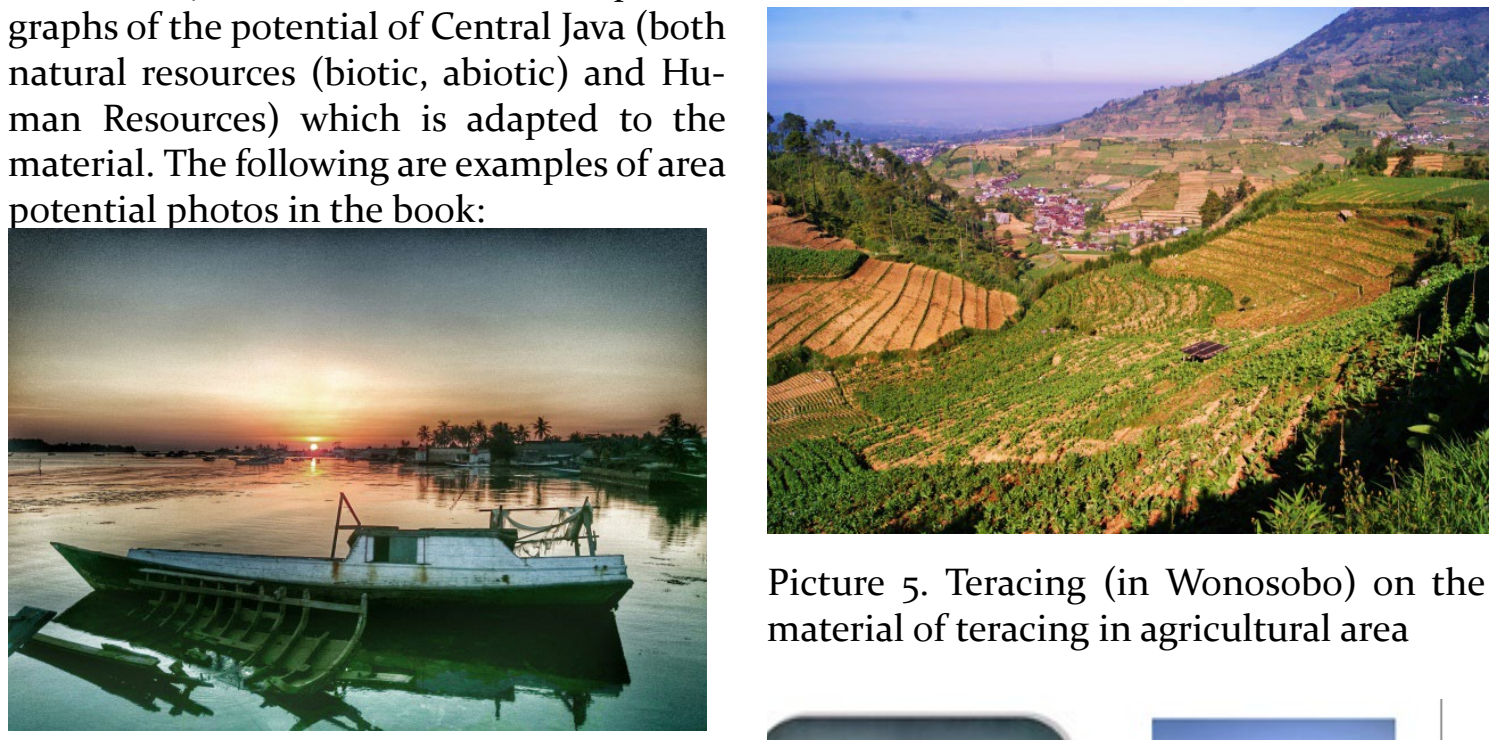

Picture 5. Teracing (in Wonosobo) on the material of teracing in agricultural area

Picture 2. Traditional Sea Transportation (in Karimunjawa) on the material of mobility infrastructures for people

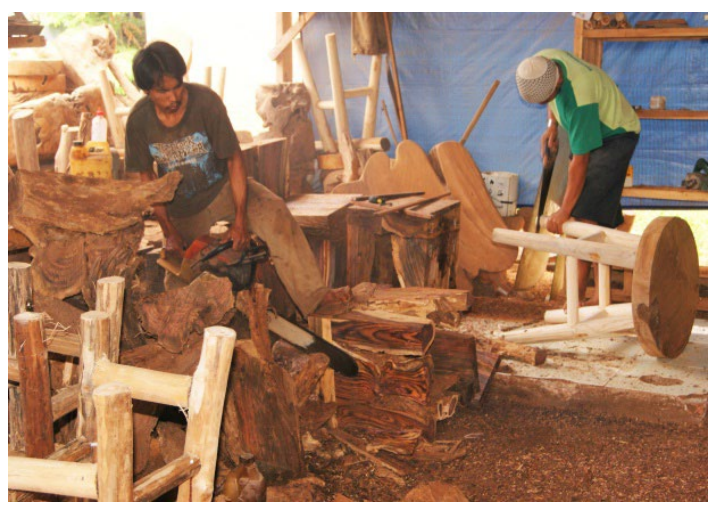

Picture 3. The activity of wood production (in Jepara) On the material of forestry activities
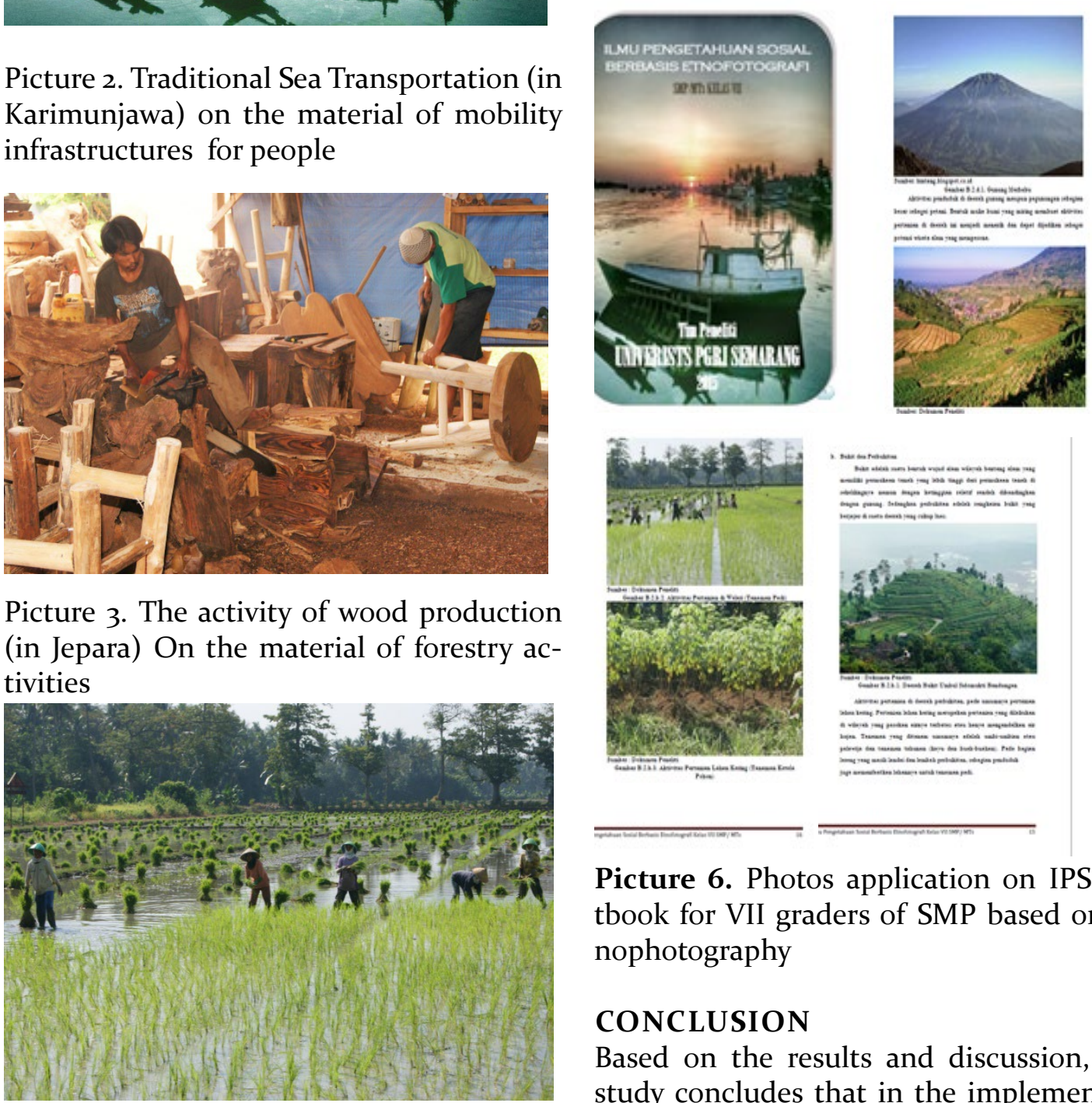

Picture 6. Photos application on IPS textbook for VII graders of SMP based on Etnophotography

\section{CONCLUSION}

Based on the results and discussion, this study concludes that in the implementati-

Picture 4. Agricultural Activities (in Kendal) on the material of agricultural activities on of Curriculum 2013, the majority of IPS Teachers in VII graders of SMP have not yet developed teaching materials in accordan- 
ce with the potential of each area. Teachers tend to choose developing material orally by using a variety of learning approaches that are contextual. The development of IPS teaching materials for VII SMP based on Etnophotography has many advantages. Therefore, it can facilitate teachers and students in the process of achievement of learning objectives.

\section{REFERENCES}

Astuti, T.M.P., Kismini, E. \& Prasetyo, K.B., 2014. The Socialization Model of National Character Education for Students in Elementary School Through Comic. Jurnal Komunitas, 6(2), pp.26o-270

Atkinson, P. and Pugsley, L., 2005. Making sense of ethnography and medical education. Medical education, 39(2), pp.228-234.

Borg, W.R. dan Gall, M.D., (1983). Educational Research An introduction. Longman, New York.

Collier, J. and Collier, M., 1986. VISUAL ANTHROPOLOGY Photography as a Research Method. Revised Edition. The University of New Mexico Press.

Davis, E.A. and Krajcik, J.S., 2005. Designing educative curriculum materials to promote teacher learning. Educational researcher, 34(3), pp.314.

Dede, C., Jass Ketelhut, D., Whitehouse, P., Breit, L. and McCloskey, E.M., 2009. A research agenda for online teacher professional development. Journal of teacher education, 6o(1), pp.8-19.

Djelita, R.D.P., 2013. Pemilihan dan Pengembangan Bahan Ajar Mata Pelajaran Pendidikan Kewarganegaraan sebagai Tuntutan Profesionaisme. E-Jurnal Dinas Pendidikan Kota Surabaya, 5(1), pp.1-8.

Ferguson, R. and Sharples, M., 2014, September. Innovative pedagogy at massive scale: teaching and learning in MOOCs. In European Conference on Technology Enhanced Learning (pp. 98-111). Springer, Cham.

Ferguson, R. and Sharples, M., 2014, September. Innovative pedagogy at massive scale: teaching and learning in MOOCs. In European Conference on Technology Enhanced Learning (pp. 98-111).
Springer, Cham.

Green, J. and Bloome, D., 2004. Ethnography and ethnographers of and in education: A situated perspective. Handbook of research on teaching literacy through the communicative and visual arts. New York: MacMillan.

Haji, S., 2011. Model Bahan Aajar Matematika SMP Berbasis Realistic Mathematics Education untuk Mengembangkan Kemahiran Matematika. Jurnal Exacta, 9(1), pp.45-50.

Harijanto, M., 2007. Pengembangan Bahan Ajar untuk Peningkatan Kualitas Pembelajaran Program Pendidikan Pembelajar Sekolah Dasar. Jurnal Didaktika,2(1), pp.216-226.

Johnson, D.W. and Johnson, R.T., 2009. An educational psychology success story: Social interdependence theory and cooperative learning. Educational researcher, 38(5), pp.365-379.

Latham, A. and Mccormack, D.P., 2007. Digital photography and web-based assignments in an urban field course: Snapshots from Berlin. Journal of Geography in Higher Education, 31(2), pp.241-256.

Meo, G., 2008. Curriculum planning for all learners: Applying universal design for learning (UDL) to a high school reading comprehension program. Preventing School Failure: Alternative Education for Children and Youth, 52(2), pp.2130

Moran, M.J. and Tegano, D.W., 2005. Moving toward Visual Literacy: Photography as a Language of Teacher Inquiry. Early Childhood Research $\mathcal{E}$ Practice, 7(1), p.nı.

Mulyana, E., et al. 2013. Pengembangan Bahan Ajar TIK SMP Mengacu pada Pembelajaran Berbasis Proyek. INVOTEC,9(2), pp.117-128.

Mushlih, A., et al., 2014. Buku IPS Kelas VII SMP Kurikulum 2013 Edisi Revisi 2014. Kementerian Pendidikan dan Kebudayaan.

Putrayasa, I.B., 2011. Kualitas Bahasa Buku Ajar. Jurnal Pendidikan dan Pengajaran IKIP PGRI Singaraja, 35(1).

Darmawan, D.R., 2012. Jalan Raya Sebagai Arena Pertunjukkan Sosial: Studi Etnofotografi Jalan Pahlawan Semarang. Solidarity: Journal of Education, Society and Culture, 1(1).

Sukmadinata, N.S. 2007. Metode Penelitian Pendidikan. Rosdakarya, Bandung. 